Societies' Clut, hope in have the pleasure of seeing you at their house in St. James -street.

Monday the Museun of the College of Surgeons will be thrown open, and will be found well worth a visit. Mr. Rothschild has also kindly invited us to see his rich museum at Tring.

Tuesday the IDuke of Bedford will show his collection of Cervide at Woburn, and there will be excursions under the auspices of the Director of the Marine Biolugical Laboratory at Plymouth, and of Prof. Herdman at Port Frin.

I trust, therefore, that you will have a delightful and in. teresting week, and that our foreign friends will carry back with them pleasant recollections of their visit here, which may induce them to return again in some future year.

\section{THE BRITISII ASSUCIATION.}

I HE preparations for the meeting in Bristol are well in hand, and by September 7 everything will be in order for the reception of visitors. It is, of course, impossible to say at present whether the meeting will be a big one, but it is expected to be, and the Executive Committee are prepared for any emergency which may arise on this score. It is not improbable, taking all things into consideration, that many will avail themselves of coming to Bristol. Owing to the distance that the meeting was held from London last year, some certainly could not spare the time for a visit to Canada, and so will take special pains to be present this year. There happen, too, to be several unusual attractions. The opening of the Cabot 'lower, though not strictly speaking connected with the Association, has been fixed for Tuesday, September 6 , and will no doubt influence many Canadians and other American visitors to come to Bristol. The Marquess of D) ufferin will perform the ceremony, and be present at the dinner in the evening. The International Conference on Terrestrial Magnetism will also meet during the Association week, and there will also be a Biological Exhibition in the Clifton Loological Gardens, which cannot fail to be of interest. Lastly, and by no means leastly; the high reputation Bristol and the neighbourhood has for objects of interest-- geological, botanical, and archirological-together with the well-known beauty of the place and the hospitality of its citizens, will induce many to attend the 1898 meeting, combined with the additional attraction of a visit from part of the Channel Fleet.

The reception room will be at the lictoria Rooms in the large hall, and will contain the usual counters for obtaining tickets, \&.c., post office, and conveniences for writing; this latter being in the gallery, access to which is obtained by a wide staircase. The small hall will be devoted to the gentlemen's smoking room, where tea and coffee can be obtained. The room known as Alderman I) aniel's, with two others, will be given over to the ladies, the rooms being suitably furnished. The local hon. treasurer and secretaries will also have their office in the Victoria Roonss.

The Directors of the Victoria Rooms Company have, in reply to a request, redecorated a large part of the building, so that the appearances are all that could be desired Cloak room for gentlemen, typewriting rooms, telephone, and a newspaper stall are all provided.

Luncheons can be obtained at the (irammar School, hard by the Victoria Rooms, and at the premises of the late Salisbury Club, which latter building will also accommodate the press and General Committee at their meetings. Lunch can also be obtained at several restaurants near.

In the Drill Hall will be an exhibition of pictures, ancient armour, and Bristol china and other objects of interest ; while the band of the Royal Horse Artillery will play there each afternoon from 4 to 6 . In the event of wet weather this place will be very convenient ; but wet or fine, it will form a comfortable lourge for those who do not wish te go to garden parties.
The section rooms are well situated, and are mostly near the reception rooms, the furthest not being any considerable distance.

Section $A$ will meet in the Lecture Theatre of the Museum, kindly lent by the Corporation ; Section $\mathrm{B}$ in the British University College ; Section $\mathrm{C}$ in the Hannah Iore Hall, Park Strect; Section D in the Victoria Chapel Schoolroom; Section $E$ in the Concert Room of the Blind Asylum; Sections F and $G$ in the Merchant Venturers' 'Technical College ; Section $\mathrm{H}$ in the Roman Catholic Schoolroom; Section $k$ in the Fine Arts Academy.

All the Bristol and Clifton Clubs have thrown their doors open to visitors, and at the Clifton College and Corporation Baths members can have an early swim it they desire it.

The presidential address and evening lectures will be delivered in the Colston Hall; the working men's lecture in the hall of the Young Men's Christian Association, St. James Square.

Tiwo conversaziones will be given : one by the Chairman of the Council (the I.ord Bishop of Hereford), the head master of Clifton College, and Mrs. Glazebrook, at Clifton College, on September 8 ; the other by the local committec, in the colston Hall on the 13 th.

As well as the Cabot dinner two others will be given: the Chamber of Commerce on the roth, the Master and Society of Merchant Venturers on the $13^{\text {th }}$; and a smoking concert will be given in honour of the President at the Merchant V'enturers' Technical College on the gth.

I) uring the week, eight garden parties will be griven to the members of the Association, several of the houses where they are to be held having most beautiful riews of the Avon and Severn. As regarc's the usual literature that will be distributed, the handbook will not be of the bulky though excellent type of the 1875 one; it will be a more compact work, printed on thin but strong paper, and the articles, which are written by local authorities on the various subjects, as complete and full as space will permit. This work was completed more than a month ago.

The excursions guides are being framed on the lines laid down by the Manchester Committee a few years ago. Each of the eighteen excursions is printed as a separate booklet, but all are enclosed in a stout cloth cover and held by a band. The map, for only one will be given, is a new one, just published by Philip, of Liverpool, and will be coloured to show the geology of the district.

\section{GLYPTIC AVD GRAPHIE ART APPLIED TO PALAONTULOGY.1}

THE Trustees of the American Museum of Natural History have undertaken a most useful work, in providing casts of a number of vertebrate fossils, obtained during recent years, from the Tertiary and Secon. dary deposits of North America, many of which can only be represented by this means in foreign museums.

But they have done even more than this; for, possessing on their staff men of artistic talent, as well as anatomical knowledge, they have set to work and pro. duced a series of models of some of the extinct monsters of the Permian, Cretaceous and Tertiary rocks of North America, restored by Mr. Charles Knight with suggestions and criticisms by the late Prof. E. D. Cope, and by Prof. Osborn and Dr. Wortman. These models (which are on a scale suitable for a small museum or lecture-table), have been executed in plaster by $\mathrm{Mr}$. Jacol Gommel. Only five are at present ready for dis-

1 "Casts, Models, Photographs, and Restorations of Fossil Vertebrates," Department of Vertebrate Palacontology, American Museum of Natura History; Central Park. New York, U.S.A. Henry F. Osborn, Curator J. I. Wortman and W. D. Matthew, Assistant Curators. 8vo. Pp. 24 7 illustrations). 